\title{
Drilling, Construction, and Caliper Logs for Well 8-3207-04, Mountain View Exploratory Well, Island of Hawaii
}

By Charles J. Ewart

U.S. GEOLOGICAL SURVEY

Open-File Report 98-643

Prepared in cooperation with the

DEPARTMENT OF WATER SUPPLY COUNTY OF HAWAII 


\title{
U.S. DEPARTMENT OF THE INTERIOR \\ BRUCE BABBITT, Secretary
}

\author{
U.S. GEOLOGICAL SURVEY
}

Charles G. Groat, Director

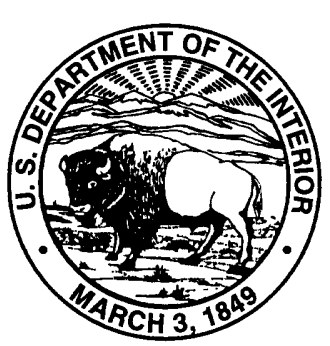

The use of firm, trade, and brand names in this report is for identification purposes only and does not constitute endorsement by the U.S. Geological Survey.

For additional information write to:

District Chief

U.S. Geological Survey

677 Ala Moana Blvd., Suite 415

Honolulu, $\mathrm{HI} 96813$
Copies of this report can be purchased from:

U.S. Geological Survey

Branch of Information Services

Box 25286

Denver, CO 80225-0286 


\section{CONTENTS}

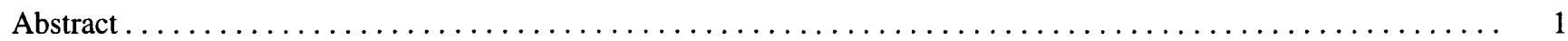

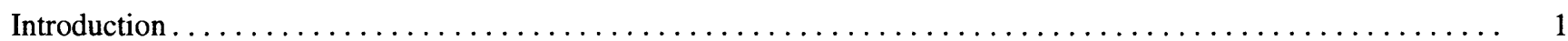

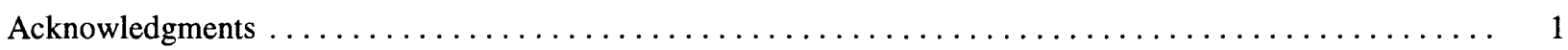

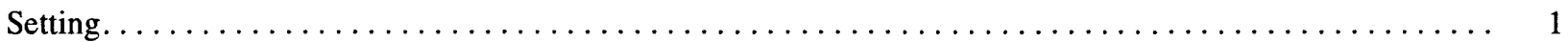

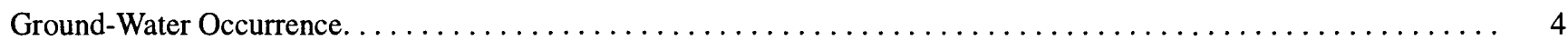

Drilling, Construction, and Caliper Logs for the Mountain View Exploratory Well (State Well Number 8-3207-04) . . 8

References Cited . . . . . . . . . . . . . . . . . . . . . . . . . . . . . . . . . .

Figures

1-4. Maps showing:

1. The Hawaiian islands, island of Hawaii, and Puna District $\ldots \ldots \ldots \ldots$

2. The Mountain View exploratory well (State well number 8-3207-04), island of Hawaii . . . . . . . 3

3. Generalized geology of the Puna District, island of Hawaii . . . . . . . . . . . . . . . .

4. Selected drilled wells and test holes in the Puna District, island of Hawaii $\ldots \ldots \ldots \ldots$

5. Diagram showing construction details of the Mountain View exploratory well (State well number

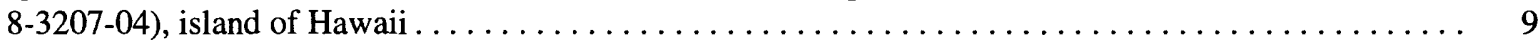

6. Graph showing caliper log for the Mountain View exploratory well (State well number 8-3207-04), island of Hawaii . . . . . . . . . . . . . . . . . . . . . . . . . . .

Tables

1. Elevation, water-level, and chloride-concentration data for selected drilled wells and shafts in the

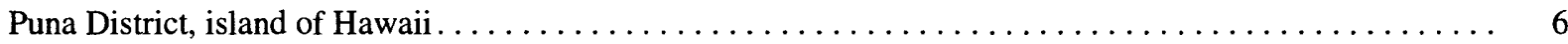

2. Construction data for the Mountain View exploratory well, island of Hawaii. . . . . . . . . . . . 8

3. Driller's log of Mountain View exploratory well (State well number 8-3207-04), island of Hawaii ........ 11

\section{Conversion Factors}

\begin{tabular}{rll}
\hline Multiply & By & To obtain \\
\hline foot (ft) & 0.3048 & meter \\
gallon (gal) & 3.785 & liter \\
mile (mi) & 1.609 & kilometer \\
square mile (mi $\left.{ }^{2}\right)$ & 2.590 & square kilometer \\
inch (in.) & 25.4 & millimeter \\
\hline
\end{tabular}

Elevations in this report are referenced to mean sea level. 


\title{
Drilling, Construction, and Caliper Logs for Well 8-3207- 04, Mountain View Exploratory Well, Island of Hawaii
}

\author{
By Charles J. Ewart
}

\section{Abstract}

The Mountain View exploratory well was drilled on private property near the Hawaii County Department of Water Supply storage tank at an elevation of 1,687 feet and about 1.4 miles southwest of the community of Mountain View. Water was encountered at a depth of 675 feet below land surface $(1,012$ feet above mean sea level) and remained at that level for the duration of drilling. The extent of this high-level water body and the nature of the impounding structures are not known. This report presents a summary of the occurrence of ground water in the Puna District and geohydrologic data and the construction details of the well.

\section{INTRODUCTION}

The Mountain View exploratory well was the third of three deep exploratory wells drilled on the island of Hawaii between September 1994 and April 1995. These wells were drilled by the U.S. Geological Survey (USGS) as part of a program of exploratory/monitor well drilling carried out in cooperation with the County of Kauai Department of Water, the County of Hawaii Department of Water Supply, and the City and County of Honolulu Board of Water Supply. The program, begun in 1993, is designed to provide hydrologic and geologic information for aquifers in three island counties. This information is vital to the understanding of the ground-water systems on each island and for estimating the amount of available ground water.

In addition to providing needed hydrogeologic information the exploratory wells completed under this program will be used as long-term monitoring sites to provide data and information for the management, pro- tection, and conservation of the ground-water resources. The rotation of the drilling rig between the islands and the duration of drilling on each island are determined by the three county water managers. Drilling sites are selected and prioritized jointly by the county water departments and the USGS.

The purpose of the Mountain View exploratory well was to provide information on the little known ground-water resources of the upper Puna District (fig. 1). The well was drilled on private property near the Hawaii County Department of Water Supply storage tank at an elevation of $1,687 \mathrm{ft}$ and about 1.4 mi southwest of the community of Mountain View (fig. 2). Water was encountered at a depth of $675 \mathrm{ft}$ below land surface $(1,012 \mathrm{ft}$ above mean sea level) and remained at that level for the duration of the drilling. The extent of this high-level water body and the nature of the impounding structures are not known. This report presents a summary of the occurrence of ground water within the Puna District and geohydrologic data and the construction details of the well.

\section{Acknowledgments}

The USGS gratefully acknowledges the assistance of the Hawaii County Department of Water Supply in site preparation and logistical support throughout the period of well construction. We also acknowledge the cooperation of Mr. and Mrs. Albert Paiva and AMFAC/JMB Hawaii, lessees and land owner respectively, for their cooperation in allowing the USGS access and permitting the well to be drilled.

\section{Setting}

The Puna District has a land area of 318,054 acres and includes the eastern slopes of Mauna Loa Volcano 


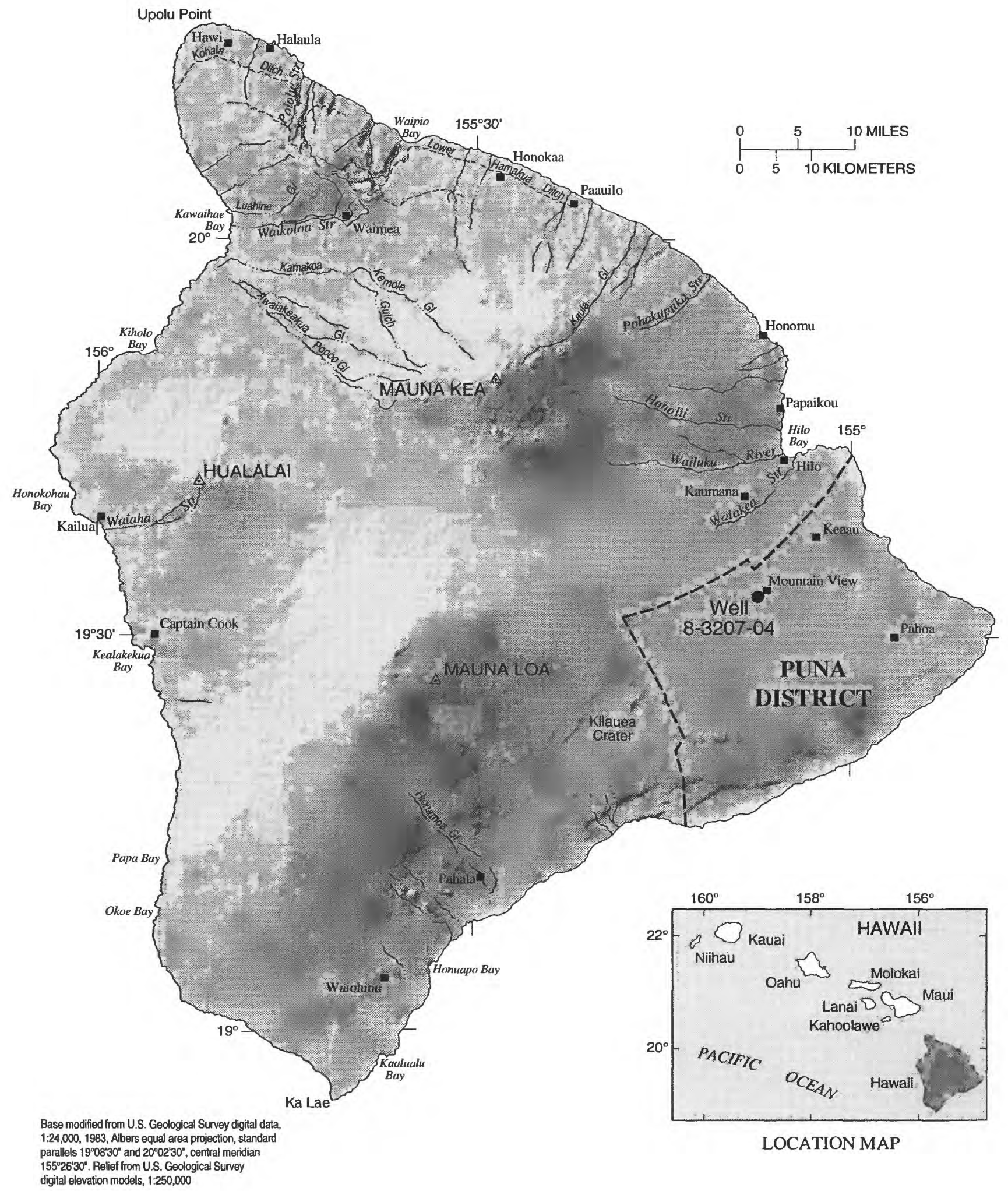

Figure 1. Location of Hawaiian islands, island of Hawaii, Puna District. 


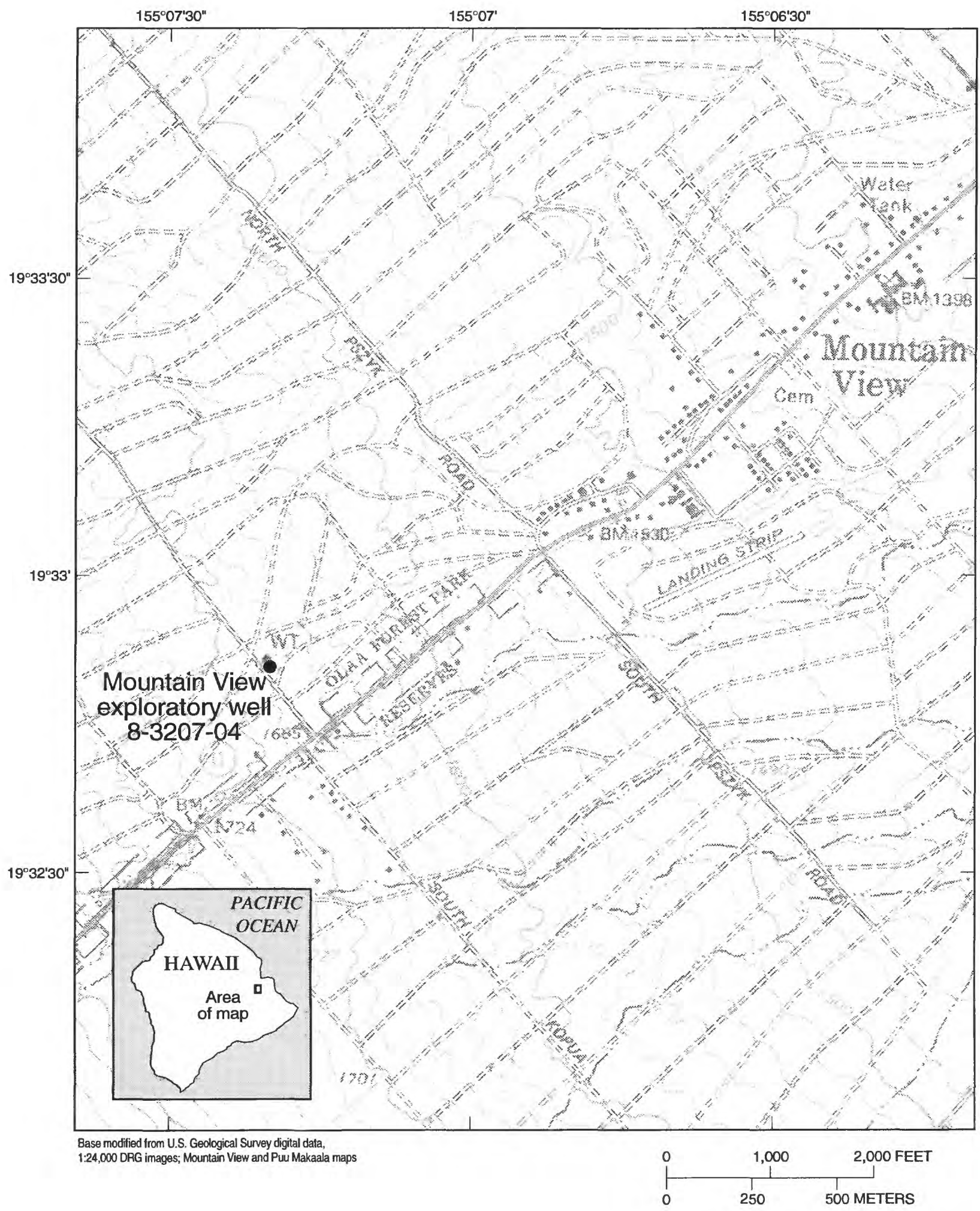

Figure 2. Location of the Mountain View exploratory well (State well number 8-3207-04), island of Hawaii. 
and the east and southeast slopes of Kilauea Volcano (fig. 1). Elevations within the district range from sea level to 5,000 ft on the slopes of Mauna Loa. Average annual rainfall near the coastal boundary is about 60 in. along the southern coast to $120 \mathrm{in}$. along the windward or eastern coast. In the interior, annual rainfall ranges from about $200 \mathrm{in}$. between the 2,000 and 3,000 ft elevations in the Mountain View area to about 120 in. at the higher elevations (Hawaii County Department of Water Supply, 1991). The Mountain View exploratory well (State well number 8-3207-04) is located adjacent to the Hawaii County Department of Water Supply's storage tank about $1.4 \mathrm{mi}$ southwest of the community of Mountain View and $900 \mathrm{ft}$ from State Highway 11 at an elevation of $1,687 \mathrm{ft}$ (fig. 2). Lava flows and pyroclastic deposits from Mauna Loa and Kilauea Volcanoes form most of the Puna District. The northern part of the District consists of the basaltic lava flows of the Kau and Kahuku Basalts while the southern part is made up of basaltic lava flows from the Puna Basalts (fig. 3). In both parts of the District pyroclastic deposits, primarily ash, which are a few feet to a few tens of feet thick are intercalated with lava flows. The lava flows of each volcano are extremely to highly permeable while the ash deposits are much less permeable (Davis and Yamanaga, 1968). Within the Puna District there is no perennial streamflow that reaches the sea.

\section{GROUND-WATER OCCURRENCE}

Ground-water occurrence in the Puna District has been described in detail by Stearns and Macdonald (1946) and Davis and Yamanaga (1968). The following is a generalized summary from these works.

Within the Puna District, ground water is found as basal water, which is that roughly lens-shaped body of freshwater near sea level floating on seawater, and as high-level ground water which may be impounded by volcanic dikes or other structures or perched on lowpermeability units such as volcanic ash. Recharge to the basal ground-water body is from direct infiltration of rainfall on the permeable land surface, from subsurface discharge of high-level ground-water bodies, and from the infiltration of water flowing over permeable rock in stream channels. Recharge to the high-level groundwater bodies is from direct infiltration of rainfall. Discharge from basal water is by springs and seeps visible at or near the coast or discharging below sea level off- shore. Discharge from high-level ground-water bodies is from springs and seeps and from sub-surface leakage to basal water bodies.

The largest and most accessible freshwater supplies in the Puna District can be found in the basal water body. The greatest volume of ground-water flow is concentrated between Hilo and Pahoa. There are few streams draining this high rainfall area and the natural discharge of ground water to the sea is estimated at several hundred million gallons per day. The water table rises inland from near sea level at the coast along gradients of between 1 and $4 \mathrm{ft} / \mathrm{mi}$. Wells located about $5 \mathrm{mi}$ inland and tapping this basal water body have freshwater levels of 15 to $19 \mathrm{ft}$ above sea level which are among the highest water levels in basal wells on the island and produce water of excellent quality with chloride concentrations of less than $25 \mathrm{mg} / \mathrm{L}$ (Davis and Yamanaga, 1973). South of Pahoa, basal water wells are located much closer to the coast with freshwater levels of 1 to 3 $\mathrm{ft}$ above sea level and chloride concentrations of 190 to $6,000 \mathrm{mg} / \mathrm{L}$. A summary of selected drilled wells in the Puna District is found in table 1 and well locations are shown in figure 4.

While numerous perched springs discharge from the lava flows of Mauna Loa near Hilo, and along the upper reaches of Waiakea Stream, which is just north of the northern boundary of the Puna District, no evidence of high-level springs is found within the District. Ten test holes were drilled in 1936 near Mountain View over an area of about $10 \mathrm{mi}^{2}$ to explore for high-level perched water. The test holes, all but one of which were located at elevations between 1,000 and $2,000 \mathrm{ft}$, were drilled to depths ranging from 60 to $160 \mathrm{ft}$ below the ground surface. Each hole penetrated one or more thin zones of water perched on ash layers or dense lava flows. Driller's notes indicated that water in the holes drained quickly when the perching beds were pierced by the drill bit. A few miles northeast of these test holes near Keaau, shaft 7 (State well number 8-3702-01) was dug in 1936. The shaft penetrated lava flows to a depth of $217 \mathrm{ft}$. A 2-ft thick ash bed was encountered at $54 \mathrm{ft}$ below ground surface and no water was perched and no water entered the shaft at that level even after heavy rain (Davis and Yamanaga, 1968).

The Mountain View exploratory well was drilled through the rocks of Mauna Loa to a depth of $1,155 \mathrm{ft}$ below ground surface in the same general area where most of the 10 test wells noted above were drilled. The 


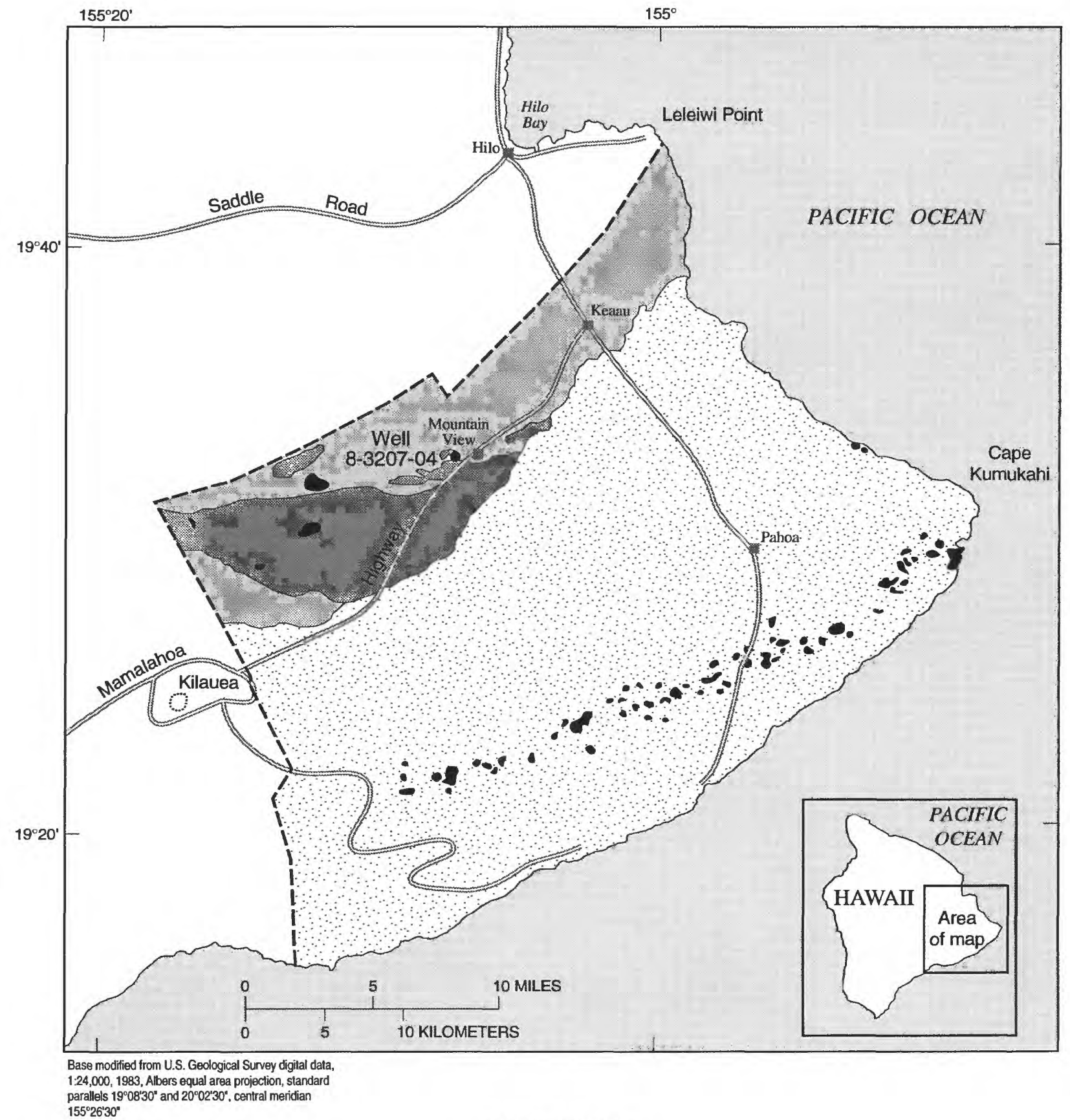

EXPLANATION

- CINDER AND SPATTER CONES

MAUNA LOA VOLCANO

Kau Basalt (Pleistocene)

Kahuku Basalt capped by

Pahala Ash (Pleistocene)

\section{KILAUEA VOLCANO}

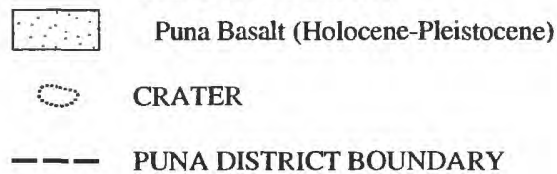

Figure 3. Generalized geology of the Puna District, island of Hawaii (modified from Davis and Yamanaga, 1968 and Langenheim and Clague, 1987). 
Table 1. Elevation, water-level, and chloride-concentration data for selected drilled wells and shafts in the Puna District, island of Hawaii

[Data from Davis and Yamanaga (1973) and State of Hawaii Commission on Water Resource Management. Datum is mean sea level; --, not sampled or no data]

\begin{tabular}{lcccc}
\hline State well no. & Year drilled & $\begin{array}{c}\text { Elevation } \\
\text { (feet) }\end{array}$ & $\begin{array}{c}\text { Water level } \\
\text { (feet) }\end{array}$ & $\begin{array}{c}\text { Chloride } \\
\text { concentration } \\
\text { (milligrams per liter) }\end{array}$ \\
\hline $8-2102-01$ & 1963 & 230 & 3 & 278 \\
$8-2487-01$ & 1961 & 752 & 3 & 72 \\
$8-2783-01$ & 1962 & 274 & 1 & 5,350 \\
$8-2986-01$ & 1960 & 705 & 18 & 2 \\
$8-3080-01$ (shaft) & 1965 & 38 & 3 & 174 \\
$8-3081-01$ & 1961 & 287 & 3 & 345 \\
$8-3185-01$ & 1964 & 402 & 11 & 16 \\
$8-3207-04$ & 1995 & 1,686 & 1,012 & - \\
$8-3389-01$ & 1960 & 427 & 19 & 12 \\
$8-3500-01$ & 1961 & 311 & 16 & 10 \\
$8-3702-01$ (shaft) & 1936 & 220 & 15 & 10 \\
$8-3800-01$ & 1950 & 40 & 7 & 120 \\
$8-3900-01$ & 1949 & 92 & 9 & 31 \\
$8-3900-02$ & 1964 & 95 & 8 & 207 \\
$8-4189-01$ & 1959 & 36 & 3 & 680 \\
\hline
\end{tabular}




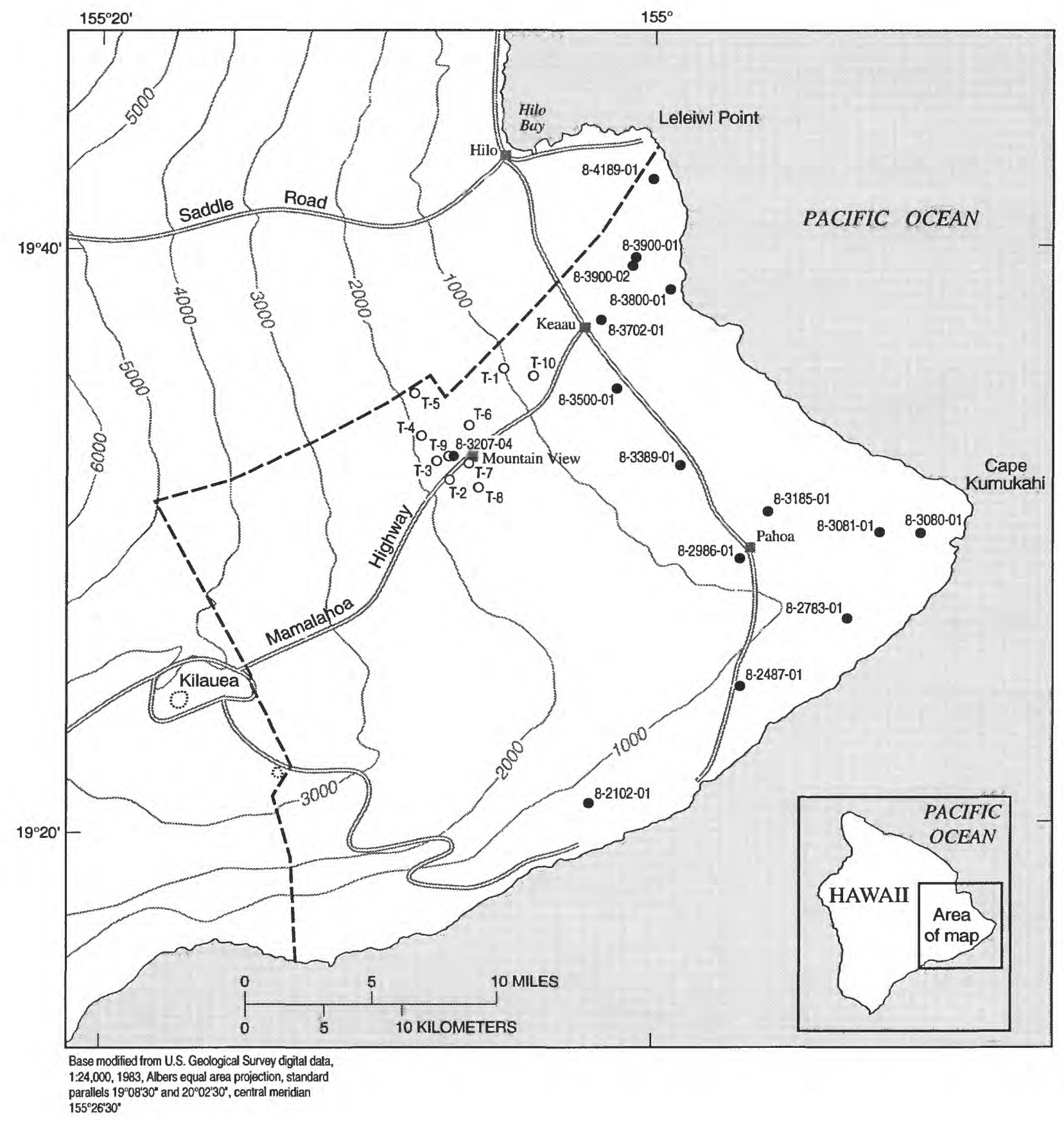

EXPLANATION

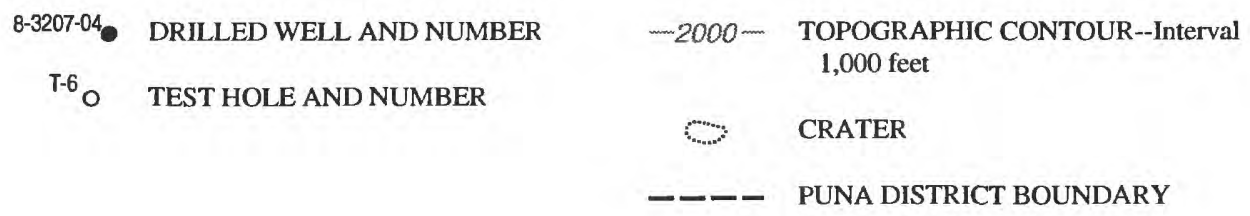

Figure 4. Selected drilled wells and test holes in the Puna District, island of Hawaii. 
Table 2. Construction data for the Mountain View exploratory well, island of Hawaii

[Datum is mean sea level; USGS, U.S. Geological Survey]

\begin{tabular}{|c|c|}
\hline Well name. & Mountain View exploratory well \\
\hline State well number. & 8-3207-04 \\
\hline Latitude and longitude ..... & $19^{\circ} 32^{\prime} 50^{\prime \prime} 155^{\circ} 07^{\prime} 21^{\prime \prime}$ \\
\hline Hawaii tax map key number . . . . . . . & $1-8-5-18$ \\
\hline 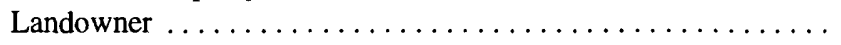 & AMFAC/JMB Hawaii \\
\hline Well completed. & March 23, 1995 \\
\hline Driller ............... & G. Wayne Heick, USGS \\
\hline Surface hole diameter $\ldots \ldots \ldots \ldots \ldots$ & $12-3 / 4$ inch \\
\hline Bottom of surface casing $\ldots \ldots \ldots \ldots \ldots \ldots \ldots \ldots \ldots \ldots \ldots \ldots$ & 1,612 feet \\
\hline Surface casing type and diameter $\ldots \ldots \ldots \ldots \ldots$ & Steel, 0.188-inch wall, 8-inch inside diameter \\
\hline Final hole diameter $\ldots \ldots \ldots \ldots \ldots \ldots \ldots \ldots \ldots \ldots \ldots \ldots \ldots \ldots \ldots$ & $6-3 / 4$ inch \\
\hline Bottom of well elevation. . . . . . . . . . . . . . . & 544 feet \\
\hline Inner casing type and diameter $\ldots \ldots \ldots \ldots \ldots \ldots \ldots$ & Steel, solid and slotted, 4.5 -inch outside diameter \\
\hline Slotted interval elevations. . . . . . . . . . . . . . & 1,122 feet to 544 feet \\
\hline Reference mark elevation (bolt in concrete pad) ......... & $1,686.86$ feet \\
\hline Measuring point (top of 4 -inch casing) elevation. . . . . . . & $1,687.84$ feet \\
\hline 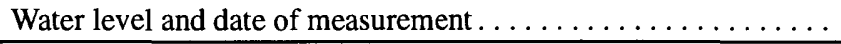 & 1,012.34 feet; March 23, 1995 \\
\hline
\end{tabular}

well encountered high-level ground water standing at an elevation of $1,012 \mathrm{ft}$ above sea level. The extent of this ground-water body and the nature of the impounding structures are not known.

\section{DRILLING, CONSTRUCTION, AND CALIPER LOGS FOR THE MOUNTAIN VIEW EXPLORATORY WELL (STATE WELL NUMBER 8-3207-04)}

The Mountain View exploratory well was drilled with an air-rotary drill rig using water, drilling foam, and polymer as the drilling fluid to stabilize the borehole and aid in the removal of cuttings and water. Samples of materials penetrated by the bit were obtained at $5 \mathrm{ft}$ intervals except at those depths where drilling-fluid circulation was lost. Drilling began on February 28, 1995 and was completed on March 23, 1995. A 12-3/4 in. hole was drilled to a depth of $75 \mathrm{ft}$ and 8-in. insidediameter steel casing was grouted in place. The remainder of the hole was drilled using a 6-3/4 in. tricone tungsten carbide bit. Well-construction data are provided in table 2 , driller's log provided in table 3 , and construction details are shown in figure 5.

A caliper log (fig. 6) was made after reaching the final depth of $1,155 \mathrm{ft}$. The caliper tool is a means to indirectly measure hole diameter and smoothness. The tool has three 16-in. spring-loaded arms that are extended when the tool is at the bottom of the hole. As the tool is slowly raised, the logging unit records the extension of the arms as they drag against the walls of the borehole. The maximum extension of the caliper arms is 32 in.

Finally, the hole was cased with 4-in. inside-diameter, flush joint, steel casing (table 3). Blank casing was installed to a depth of $660 \mathrm{ft}$ and slotted casing from 660 $\mathrm{ft}$ to $1,120 \mathrm{ft}$, as $12 \mathrm{ft}$ of hole was lost due to caving. The 4.5-in. outside-diameter casing was grouted from a depth of $95 \mathrm{ft}$ to the surface and a $4-\mathrm{ft}^{2} 4$-in. thick concrete pad was constructed.

\section{REFERENCES CITED}

Davis, D.A., and Yamanaga, George, 1968, Preliminary report on the water resources of the Hilo-Puna area, Hawaii: Hawaii Division of Water and Land Development, Department of Land and Natural Resources, Circular C45, $38 \mathrm{p}$.

Davis, D.A., and Yamanaga, George, 1973, Water resources summary, island of Hawaii: Hawaii Division of Water and Land Development, Department of Land and Natural Resources, Report R47, 42 p.

Hawaii Commission on Water Resource Management, 1991, Hawaii County water use and development plan: Hawaii Department of Land and Natural Resources Report, variously paged, 4 app., $15 \mathrm{pl}$.

Langenheim, V.A.M., and Clague, D.A., 1987, The Hawaiian-Emperor volcanic chain, chap. 1 of Decker, R.W., Wright, T.L., and Stauffer, P.H., eds., Volcanism in Hawaii: U.S. Geological Survey Professional Paper 1350 , v. 1, p. 55-84.

Stearns, H.T., and Macdonald, G.A., 1946, Geology and ground-water resources of the island of Hawaii: Hawaii Division of Hydrography Bulletin 9, 363 p. 
Table 3. Driller's log of Mountain View exploratory well (State well number 8-3207-04), island of Hawaii [Drill crew--G. Wayne Heick, Kimo K. Akina, Charles J. Ewart; ${ }^{\circ}$ F, degrees Farenheit]

\begin{tabular}{|c|c|c|}
\hline Date & $\begin{array}{l}\text { Depth } \\
\text { (feet) }\end{array}$ & Log/remarks \\
\hline \multirow[t]{12}{*}{$2 / 28 / 95$} & & Begin drilling \\
\hline & $0-3$ & Fill debris, dry to damp \\
\hline & $3-7$ & Grey aa core, hard, dry \\
\hline & $7-15$ & Grey aa core, uniform, hard, dry \\
\hline & $15-20$ & Grey-brown aa core, hard, dry \\
\hline & $20-23$ & Red, oxidized aa, medium soft, moist \\
\hline & $23-30$ & Grey-brown, aa core, medium to hard, dry \\
\hline & $30-61$ & Blue-gray aa core, hard, dry \\
\hline & $61-63$ & Void, lost circulation \\
\hline & $63-68$ & Blue rock, very hard, no return \\
\hline & $68-73$ & Broken aa, clinker zone?, no return \\
\hline & $73-74$ & Aa core?, hard, no return \\
\hline $3 / 1 / 95$ & & Weld pipe, set surface casing \\
\hline \multirow[t]{15}{*}{$3 / 6 / 95$} & $74-76$ & Aa core, very hard, good returns \\
\hline & $76-78$ & Puka rock, good returns \\
\hline & $78-82$ & Aa core, hard, uniform, good returns \\
\hline & $82-90$ & Aa, broken, clinkery, caving in hole \\
\hline & $90-93$ & Aa core, medium hard, good returns \\
\hline & $93-109$ & Aa core, very hard, good returns \\
\hline & $109-117$ & Red puka rock, medium soft, good returns \\
\hline & $117-122$ & Grey aa core, medium hard, good returns \\
\hline & $122-130$ & Aa, broken, loose, clinkery, good returns \\
\hline & $130-134$ & Aa core, hard, red-brown to grey, good returns \\
\hline & $134-143$ & Aa, broken, red, clinkery, medium soft, returns okay \\
\hline & $143-146$ & Aa core, brown to grey, hard, good returns \\
\hline & $146-150$ & Aa, soft, broken, grey-red, good returns \\
\hline & $150-156$ & Aa core, grey, medium hard, some breaks, return okay \\
\hline & $156-168$ & Blue rock, very hard, uniform, good returns \\
\hline \multirow[t]{8}{*}{$3 / 7 / 95$} & $168-179$ & Blue rock, very hard, good returns \\
\hline & $179-183$ & Void, lost circulation \\
\hline & $183-194$ & Aa, broken, clinkery, grey to red, medium soft \\
\hline & 194-196 & Aa core, medium hard, red to grey, good returns \\
\hline & 196-209 & Aa, grey to red, medium soft, clinkery, good returns \\
\hline & $209-212$ & Aa core, red-brown, medium hard, good returns \\
\hline & $212-248$ & Aa, red, soft, loose, good returns \\
\hline & $248-252$ & Aa core, red to brown, medium hard, good returns \\
\hline \multirow[t]{14}{*}{$3 / 8 / 95$} & $252-260$ & Aa core, brown-grey, hard, good returns \\
\hline & $260-267$ & Aa, grey-red, broken, soft, good returns \\
\hline & $267-276$ & Red ash?, very soft, possible water \\
\hline & $276-281$ & Aa, grey-red, broken, medium soft, good returns \\
\hline & $281-299$ & Aa core, blue-grey, hard, good returns \\
\hline & 299-304 & Red ash?, very soft, clay like, good returns \\
\hline & $304-324$ & Aa, reddish brown, broken, soft, good returns \\
\hline & $324-336$ & Aa core, medium hard, uniform, good returns \\
\hline & $336-345$ & Aa, grey-red, broken, clinkery, soft, return okay \\
\hline & $345-377$ & Aa core, grey-green, olivine, medium hard, returns okay \\
\hline & $377-388$ & Aa, red-pink, broken, soft, stable, good returns \\
\hline & $388-393$ & Aa core, pink-grey, good returns \\
\hline & $393-406$ & Aa, grey-reddish brown, medium soft, returns okay \\
\hline & $406-421$ & Aa core, red-grey, medium hard, good returns \\
\hline
\end{tabular}


Table 3. Driller's log of Mountain View exploratory well (State well number 8-3207-04), island of Hawaii--Continued [Drill crew--G. Wayne Heick, Kimo K. Akina, Charles J. Ewart; ${ }^{\circ}$ F, degrees Farenheit]

\begin{tabular}{|c|c|c|}
\hline Date & $\begin{array}{l}\text { Depth } \\
\text { (feet) }\end{array}$ & Log/remarks \\
\hline & $421-429$ & Aa, red, broken, loose, good returns \\
\hline & $429-441$ & Aa core, red-grey, broken, medium hard, good returns \\
\hline & $441-452$ & Aa, grey-red, broken, medium hard, good returns \\
\hline \multirow[t]{7}{*}{$3 / 9 / 95$} & $452-455$ & $\mathrm{Aa}$, grey-red, loose, broken, good returns \\
\hline & $455-472$ & Aa core, grey-lt.brown, medium hard, uniform, return okay \\
\hline & $472-477$ & Aa, grey-brown, loose, soft, good returns \\
\hline & $477-479$ & Ash layer?, red, very soft, good returns \\
\hline & $479-496$ & Aa, red-brown, medium hard to soft, good returns \\
\hline & $496-510$ & Aa core, grey-brown, medium hard, good returns \\
\hline & $510-512$ & Void, lost circulation, stiffer foam but no good \\
\hline \multirow[t]{14}{*}{$3 / 10 / 95$} & $512-528$ & $\mathrm{Aa}$, very broken, unstable, no returns \\
\hline & $528-550$ & Aa core, medium hard, grey, no returns \\
\hline & $550-569$ & Aa, red-grey, medium to soft, no returns \\
\hline & $569-582$ & Aa core, red-grey, soft, broken, some returns \\
\hline & $582-596$ & Aa, grey-red, soft, broken, some returns \\
\hline & $596-604$ & Aa core, red-grey, hard, some broken, good returns \\
\hline & $604-620$ & Aa, grey-red, broken, medium soft, good returns \\
\hline & $620-626$ & Aa core, red-grey, good returns \\
\hline & $626-630$ & $\mathrm{Aa}$, red, medium soft, good returns \\
\hline & $630-632$ & Ash? grey, soft, good returns \\
\hline & $632-647$ & $\mathrm{Aa}$, grey-red, medium soft, good returns \\
\hline & $647-651$ & Aa core, grey-blue, hard, uniform, good returns \\
\hline & $651-679$ & Aa, grey, medium hard to soft, unstable \\
\hline & $679-692$ & Aa core, grey-brown, hard, return lost about 680 feet \\
\hline \multirow[t]{10}{*}{$3 / 11 / 95$} & $692-734$ & $\mathrm{Aa}$, red, broken, clinkers, return back at 712 feet \\
\hline & $734-750$ & Aa core, red-grey, good returns \\
\hline & $750-765$ & Aa, red-grey, medium soft, spotty returns \\
\hline & $765-780$ & Aa core, red to grey, medium to hard, good returns \\
\hline & $780-786$ & Aa, grey-red, loose, broken, soft, returns okay \\
\hline & $786-799$ & Aa core, red to grey, broken, good returns \\
\hline & $799-830$ & Aa, grey-red, broken, good returns, water?? \\
\hline & $830-844$ & Aa core, grey-brown, uniform, good returns \\
\hline & & $\begin{array}{l}\text { Increase in air back pressure at } 834 \text { feet, ran static air test for } 10 \text { minutes. Water at } \\
824 \text { feet }\end{array}$ \\
\hline & $844-854$ & Aa, red-grey, broken, medium to soft, good returns \\
\hline \multirow[t]{7}{*}{$3 / 12 / 95$} & $854-908$ & Aa, grey to red, broken, unconsolidated, return okay \\
\hline & & Olivine in samples from $880-895$ feet, water temperature $66.2^{\circ} \mathrm{F}$ \\
\hline & $908-913$ & Aa core, red to grey, medium hard, good returns \\
\hline & $913-1,023$ & Aa, grey to red, unconsolidated, soft, more water \\
\hline & & Water temperature at 940 feet $64.9^{\circ} \mathrm{F} ; 63.7^{\circ} \mathrm{F}$ at 980 feet \\
\hline & $1,023-1,031$ & Aa core, grey with some olivine, medium hard, return okay \\
\hline & $1,031-1,034$ & Aa, broken, grey-red, medium to soft, good returns \\
\hline \multirow[t]{8}{*}{$3 / 13 / 95$} & $1,034-1,046$ & Aa core, red-grey, uniform, good returns \\
\hline & $1,046-1,051$ & Aa, grey to red, medium to soft, good returns \\
\hline & $1,051-1,054$ & Blue rock, medium hard, good returns \\
\hline & $1,054-1,060$ & Aa, grey with some red, medium to soft, good returns \\
\hline & $1,060-1,074$ & Aa core, grey, medium hard, uniform, good returns \\
\hline & $1,074-1,089$ & Aa, grey to red, broken, some clinkers, returns okay \\
\hline & $1,089-1,115$ & Blue rock, very hard, some breaks, good returns \\
\hline & $1,115-1,121$ & Aa, grey-red, broken, voids, good returns \\
\hline
\end{tabular}


Table 3. Driller's log of Mountain View exploratory well (State well number 8-3207-04), island of Hawaii--Continued [Drill crew--G. Wayne Heick, Kimo K. Akina, Charles J. Ewart; ${ }^{\circ}$ F, degrees Farenheit]

\begin{tabular}{|c|c|c|}
\hline Date & $\begin{array}{l}\text { Depth } \\
\text { (feet) }\end{array}$ & Log/remarks \\
\hline & $1,121-1,126$ & Aa, void, very soft, possible cinder, returns okay \\
\hline & $1,126-1,137$ & Aa core, red to grey, medium hard, good returns \\
\hline & $1,137-1,141$ & Aa, grey-red, very loose, small clinkers, return okay \\
\hline & $1,141-1,155$ & $\begin{array}{l}\text { Aa core, grey, very hard, good returns, water temp } 61.7^{\circ} \mathrm{F} \text { at } 1,155 \text { feet. Hole } \\
\text { standing okay. Drilling ended---Total depth } 1,155 \text { feet }\end{array}$ \\
\hline \multirow[t]{3}{*}{$3 / 14 / 95$} & & Stripped out tools, debris in hole, tools dragging \\
\hline & & $\begin{array}{l}\text { Attempt to get depth to water at } 1,100 \text {. Hole plugged at } 90 \text { feet. Ran tools back in } \\
\text { drilled to } 140 \text { feet, pulled tools. Attempt to get depth to water, bridge at } 220 \\
\text { feet. Ran tools in drilled to } 360 \text {, stripped out }\end{array}$ \\
\hline & & Another bridge at 624 feet \\
\hline $3 / 15 / 95$ & & Loaded casing at yard, set up to perforate pipe \\
\hline $3 / 20 / 95$ & & Finished perforating. \\
\hline $3 / 21 / 95$ & & $\begin{array}{l}\text { Drilled from bridge at } 624 \text { to } 712 \text { feet. Bit plugged. Unplugged bit drilled to } 852 \text {. } \\
\text { Pulled tools, added de-foamer to hole. Measured depth to water to be } 728.2 \text { at } \\
1,450 \text { (poor reading). Tripped to bottom of hole. Lost } 12 \text { feet of hole due to } \\
\text { caving. Total depth now } 1,143 \text { feet }\end{array}$ \\
\hline $3 / 22 / 95$ & & $\begin{array}{l}\text { Pull tools out. Caliper log hole at } 12 \text { noon. Cased hole } 1330-1900 \text { hours. Depth to } \\
\text { water at } 1900 \text { hours is } 678.6 \text { feet, from drill table. Total depth of hole is } 1,143 \\
\text { feet }\end{array}$ \\
\hline $3 / 23 / 95$ & & $\begin{array}{l}\text { Depth to water } 675.5 \text { feet from ground level at } 0900 \text {, grouted hole. Constructed } \\
\text { pad. Job complete }\end{array}$ \\
\hline $3 / 24 / 95$ & & Depth to water 677.06 feet from top of 4 -inch casing at 1100 \\
\hline $3 / 25 / 95$ & & Depth to water 677.50 feet from top of 4 -inch casing at 0900 \\
\hline $3 / 26 / 95$ & & Depth to water 677.30 feet from top of 4 -inch casing at 0900 \\
\hline $3 / 27 / 95$ & & Depth to water 677.00 feet from top of 4 -inch casing at 1300 \\
\hline $3 / 28 / 95$ & & Depth to water 677.30 feet from top of 4 -inch casing at 1300 \\
\hline
\end{tabular}




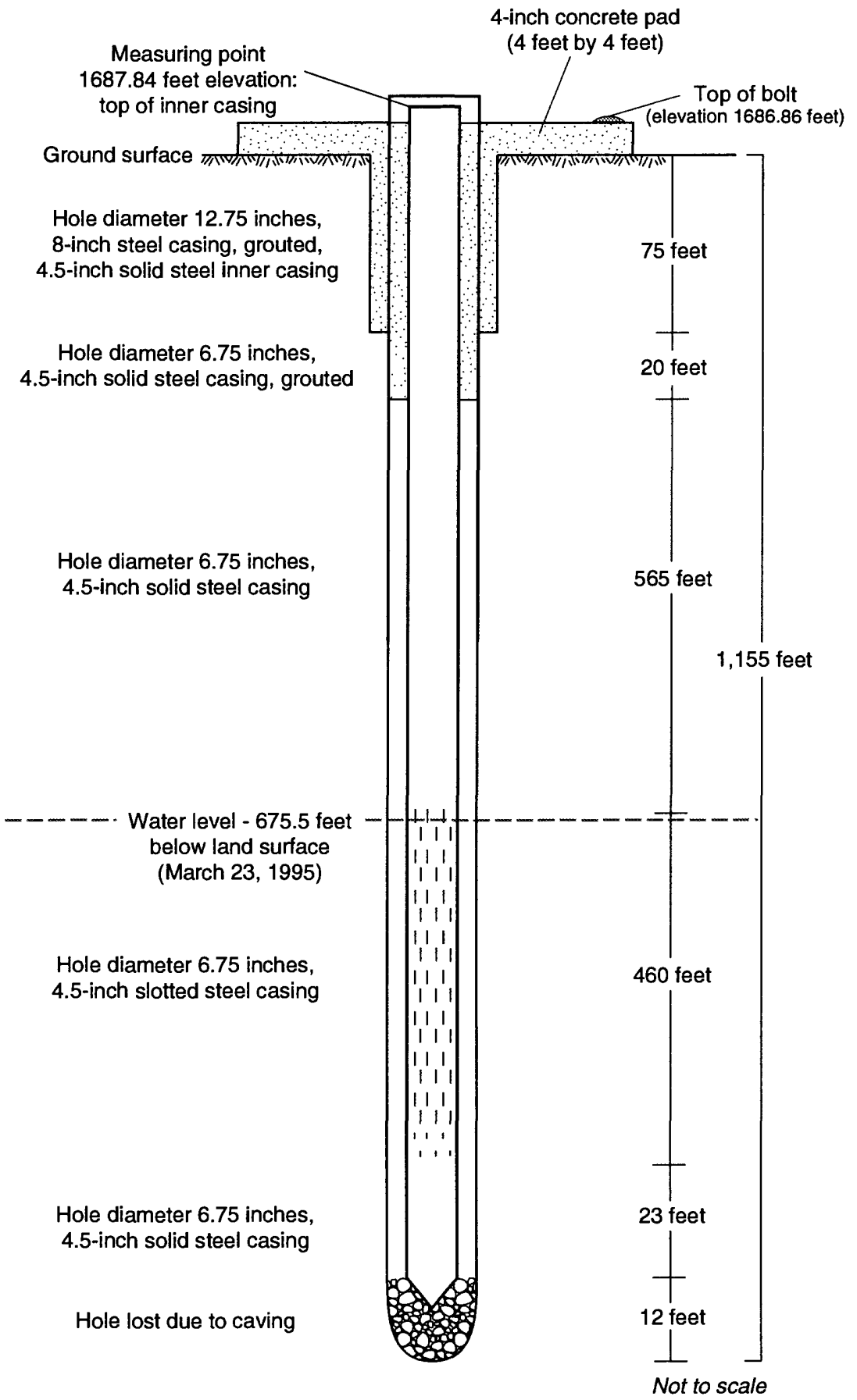

Figure 5. Construction details of the Mountain View exploratory well (State well number 8-3207-04), island of Hawaii. 


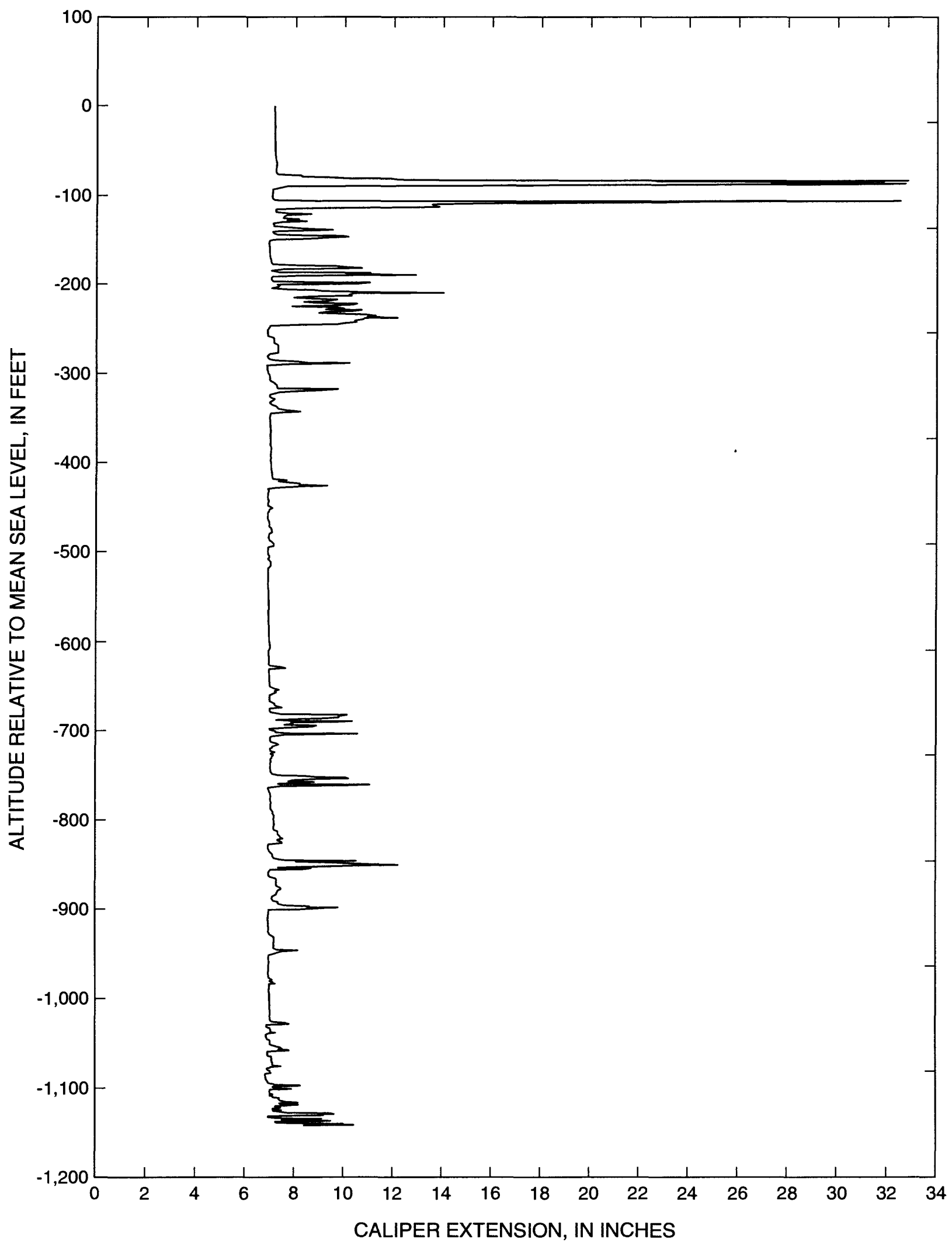

Figure 6. Caliper log for the Mountain View exploratory well (State well number 8-3207-04), island of Hawaii. 